\title{
Kejadian Demam Setelah Imunisasi DTwP-1 pada Anak yang Mendapat ASI dan Tidak Mendapat ASI di Kota Palembang
}

Firdinand, ${ }^{*}$ Rismarini, ${ }^{*}$ Yudianita Kesuma, ${ }^{*}$ Kms Yakub Rahadiyanto**

*Bagian Kesehatan Anak, ${ }^{* *}$ Bagian Patologi Klinik Fakultas Kedokteran Universitas Sriwijaya RS Moh. Hoesin, Palembang

Latar belakang. Di beberapa provinsi di Indonesia, cakupan imunisasi masih rendah. Salah satu alasan orang tua tidak memberikan imunisasi karena demam yang terjadi setelah imunisasi, khususnya imunisasi DPT. Penelitian sebelumnya menunjukkan bahwa kejadian demam setelah vaksinasi dengan DTaP dapat dicegah dengan ASI eksklusif. Data mengenai pengaruh ASI terhadap kejadian demam setelah imunisasi dengan vaksin DTwP masih sedikit.

Tujuan. Mengetahui pengaruh pemberian ASI dalam mencegah demam pada anak setelah imunisasi DPT-1 di Kota Palembang.

Metode. Penelitian merupakan studi kohort prospektif yang dilakukan di tujuh Puskesmas di Kota Palembang yang dipilih secara cluster sampling. Sampel penelitian adalah anak usia 2-4 bulan yang mendapat imunisasi DPT-1. Anak dikelompokkan menjadi kelompok ASI eksklusif, parsial, dan susu formula. Orang tua diajarkan cara mengukur suhu di rumah dan mencatat hasil pengukuran di kartu harian. Perbandingan kejadian demam antar kelompok dihitung dengan chi square test.

Hasil. Didapatkan 379 bayi masuk dalam penelitian. Demam terjadi pada $246(64,9 \%)$ anak. Jumlah anak yang mengalami demam pada kelompok ASI eksklusif 73 (19,2\%), ASI parsial $75(19,7 \%)$, dan susu formula $98(25,8 \%)$ anak $(\mathrm{p}=0,001)$. Risiko relatif terjadinya demam pada kelompok susu formula adalah 1,38 (IK95\%: 1,16-1,65) dibandingkan kelompok ASI eksklusif dan 1,33(IK 95\%: 1,12-1,58) dibandingkan kelompok ASI parsial.

Kesimpulan. Pemberian ASI dapat menurunkan kejadian demam setelah imunisasi DTwP-1. Sari Pediatri 2015;17(1):52-8.

Kata kunci: pola ASI, imunisasi DTwP-1, demam

\section{Incidence of Fever After DTwP-1 Immunization in Breastfed and Non Breastfed Children in Palembang}

Firdinand, ${ }^{*}$ Rismarini, ${ }^{*}$ Yudianita Kesuma, ${ }^{*}$ Kms Yakub Rahadiyanto, ${ }^{* *}$

Background. Indonesia generally has good immunization coverage except in few provinces. Fever occuring after immunization, especially DPT imunization, is one of the main reason for parental reluctancy to give immunization to their children. Previous study found that incidence of fever after DTaP immunization can be reduced by giving breastmilk. However, there are still limited amount of data on the effect of breastfeeding in reducing the incidence of fever after DTwP immunization.

Objective. To determine the effect of breastfeeding in preventing fever in infants after DPT1 imunization in Palembang.

Methods. This study was a prospective cohort study conducted at seven Primary Health Centers in Palembang, selected by cluster sampling. Subjects were infants aged 2-4 months who received DPT1 immunization. Infants were grouped into exclusive breastfeeding, partial breastfeeding and formula. Parents were taught how to measure temperature at home and to record the measurement. Fever was defined as axillary temperature $>37.50 \mathrm{C}$. Incidence of fever between groups was compared using chi square test.

Results. A total of 379 infants were included in this study. Fever occured in 246 infants (64.9\%). The number of infants with fever in the exclusive breastfed group were 73 (19.2\%), partial breastfeeding group 75 (19.7\%), and formula group 98 (25.8\%), with p value of 0.001 . The relative risk for fever in the formula group was 1.38 (95\% CI: 1.16-1.65) compared to exclusive breastfeeding group and 1.33 (95\% CI: 1.12 to 1.58) compared to partial breastfeeding group.

Conclusion. Breastfeeding can reduce incidence of fever after DTwP-1 imunization. Sari Pediatri 2015;17(1):52-8.

Keywords: patterns of breastfeeding, DTwP-1 imunization, Fever.

Alamat korespondensi: Dr. Firdinand, Sp.A. Bagian Kesehatan Anak, Fakultas Kedokteran, Universitas Sriwijaya, Jl. Sudirman KM 3.5 Palembang, 30126, Indonesia. Telepon +62811726264. E-mail: ikhsankhairy@yahoo.co.id 
$\mathrm{K}$

egiatan imunisasi merupakan salah satu kegiatan prioritas Kementerian Kesehatan sebagai salah satu bentuk nyata komitmen pemerintah untuk mencapai Millenium Development Goals (MDGs). Tujuan utama kegiatan imunisasi adalah menurunkan angka kesakitan dan kematian akibat penyakit yang dapat dicegah dengan imunisasi (PD3I), terutama pada balita seperti penyakit TBC, polio, campak, difteri, dan pertusis. ${ }^{1}$

Di beberapa provinsi di Indonesia, cakupan imunisasi dasar sudah cukup bagus, tetapi cakupan sebagiannya lagi masih rendah sehingga masih memerlukan usaha khusus. ${ }^{1}$ Salah satu alasan orang tua memutuskan tidak memberi imunisasi pada anaknya karena kejadian demam setelah imunisasi. Imunisasi yang paling banyak menyebabkan demam adalah DPT. Demam dipicu oleh respon imun dan respon inflamasi terhadap komponen vaksin DTwP. Pemberian vaksin DTwP bahkan dapat mengakibatkan demam tinggi, kejang dan syok, jadi sangat penting untuk mengetahui langkah pencegahannya. ${ }^{2-4}$

Pada penelitian sebelumnya yang dilakukan Pisacane $\mathrm{dkk}^{5}$ dinyatakan terdapat hubungan antara menyusui dengan rendahnya kejadian demam pada bayi yang mendapat vaksin DTaP. Bayi yang mendapat ASI akan memiliki respon imun yang berbeda terhadap penyakit dibandingkan dengan bayi yang tidak diberi ASI. Respon imun yang berbeda ini disebabkan karena faktor anti-inflamasi dan faktor imunomodulator yang terdapat di dalam ASI.

Di Indonesia saat ini, imunisasi DPT masih menggunakan vaksin DTwP yang memiliki reaktogenisitas lebih tinggi sehingga kejadian demam lebih tinggi dibandingkan bayi yang mendapat vaksin DTaP. ${ }^{2,6}$ Tujuan penelitian ini adalah untuk mengetahui pengaruh pemberian ASI dalam mencegah kejadian demam pada bayi setelah pemberian imunisasi DPT 1 yang menggunakan vaksin DTwP di Kota Palembang.

\section{Metode}

Rancangan penelitian merupakan studi kohort prospektif untuk membandingkan kejadian demam setelah imunisasi DPT 1 pada anak yang mendapat ASI dan tidak mendapat ASI di Kota Palembang. Penelitian ini dilakukan di tujuh Puskesmas di Kota Palembang yang dipilih secara cluster sampling dari bulan Januari sampai dengan Maret 2014. Puskesmas tersebut adalah Puskesmas Dempo, Sekip, Plaju, Pembina, Kenten, Kalidoni, dan Selincah. Pengambilan sampel dilakukan dengan cara consecutive sampling. Sampel penelitian adalah anak berusia 2-4 bulan yang datang ke Puskesmas untuk mendapatkan imunisasi DPT 1 dan memenuhi kriteria inklusi.

Kriteria inklusi adalah anak yang berusia 2-4 bulan yang dijadwalkan mendapat imunisasi DPT 1 dan mendapat persetujuan dari orang tua dengan menandatangani informed consent. Kriteria eksklusi adalah anak dengan berat badan $<2500 \mathrm{gr}$, mengalami demam saat akan dilakukan imunisasi DPT 1, memiliki riwayat kejang demam atau dengan kelainan bawaan/kelainan kongenital.

Pemberian imunisasi DPT 1 di Puskesmas dilakukan pada saat jam kerja atau sebelum pukul 12.00 WIB oleh petugas imunisasi. Sebelum imunisasi, suhu tubuh anak diukur untuk memastikan tidak demam. Setelah pemberian imunisasi, ibu diberi termometer digital mengukur suhu tubuh di rumah setiap enam jam selama tiga hari berturut-turut, atau kapan pun bila ibu merasa badan anaknya hangat. Bila hal itu terjadi, ibu disarankan untuk memeriksa suhu anak setiap jam dan banyak minum. Setelah suhu mencapai $>37,5^{\circ} \mathrm{C}$ pada pengukuran aksila, barulah anak dinyatakan demam dan dapat diberi obat antipiretik (parasetamol) dengan dosis $10-15 \mathrm{mg} / \mathrm{kg}$.

Perbandingan kejadian demam antar kelompok dianalisis dengan uji chi square. Rata-rata perbedaan suhu dianalisis dengan uji Kruskal Wallis. Dilakukan penghitungan risiko relatif (RR) untuk terjadinya demam antar kelompok. Analisis dilakukan menggunakan peranti lunak SPSS 16 for Windows.

\section{Hasil}

Selama periode penelitian didapatkan 390 anak berusia 2-4 bulan yang mendapat imunisasi DTwP-1. Sebelas orang anak dieksklusi dari penelitian, enam anak dengan berat badan kurang dari 2500 gram, dan empat karena beralamat rumah di luar Kota Palembang, dan satu anak karena orang tua keberatan. Dengan demikian, sampel penelitian adalah 379 yang terdiri dari 183 laki-laki dan 196 perempuan (Gambar 1).

Berdasarkan pola pemberian ASI, subjek penelitian dimasukkan ke dalam tiga kelompok. Anak yang mendapat ASI eksklusif 128 orang (65 laki-laki, 63 
390 bayi (L:188; P:202)

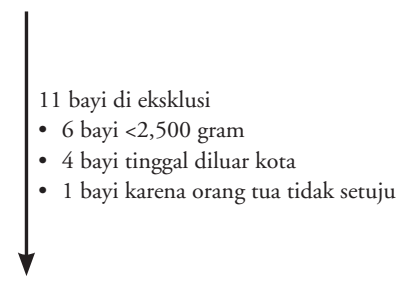

379 bayi (L:183; P:196)

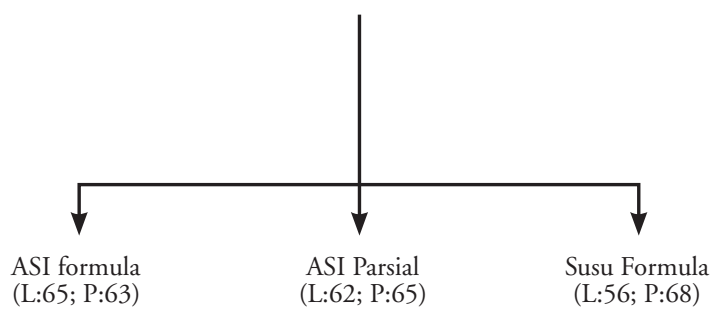

Gambar 1. Alur pengambilan subjek penelitian. perempuan). Anak yang mendapat ASI parsial 127 orang (62 laki-laki, 65 perempuan). Anak yang mendapat susu formula 124 orang (56 laki-laki, 68 perempuan).

Rerata usia anak adalah 2,64 $\pm 0,66$ bulan. Status gizi diukur dengan menggunakan $Z$-score WHO untuk berat badan menurut panjang badan. Berdasarkan status gizi kelompok terbanyak adalah anak dengan gizi baik dan kelompok yang paling sedikit adalah anak dengan gizi lebih. Berdasarkan status pendidikan ibu, kelompok terbanyak adalah ibu dengan pendidikan SMA dan yang paling sedikit adalah ibu dengan pendidikan Diploma (D1/D3). Berdasarkan jumlah penghasilan orang tua per bulan, kelompok terbanyak adalah orang tua dengan penghasilan antara 1-2 juta rupiah dan kelompok yang paling sedikit adalah penghasilan orang tua $>4$ juta rupiah. Berdasarkan jumlah anak dalam keluarga, kelompok terbanyak adalah jumlah anak 1 orang dan yang paling sedikit adalah jumlah anak $>4$ orang (Tabel 1).

Tabel 1. Karakteristik umum subjek penelitian

\begin{tabular}{|c|c|c|c|c|}
\hline Karakteristik subjek & $\begin{array}{c}\text { Eksklusif } \\
\mathrm{n}(\%)\end{array}$ & $\begin{array}{c}\text { Parsial } \\
\mathrm{n}(\%)\end{array}$ & $\begin{array}{c}\text { Formula } \\
\mathrm{n}(\%)\end{array}$ & $\begin{array}{c}\text { Jumlah } \\
\mathrm{n}(\%)\end{array}$ \\
\hline \multicolumn{5}{|l|}{ Jenis kelamin } \\
\hline Laki-laki & $65(17,1)$ & $62(16,3)$ & $56(14,7)$ & $183(48,3)$ \\
\hline Perempuan & $63(16,6)$ & $65(17,1)$ & $68(17,9)$ & $196(51,7)$ \\
\hline Rerata usia (Bulan, $($ rerata $\pm S D)$ & $2,59 \pm 0,65$ & $2,71 \pm 0,63$ & $2,61 \pm 0,70$ & $2,64 \pm 0,66$ \\
\hline \multicolumn{5}{|l|}{ Status gizi } \\
\hline Kurang & $20(5,2)$ & $13(3,4)$ & $12(3,1)$ & $45(11,4)$ \\
\hline Baik & $108(28,5)$ & $110(29,0)$ & $103(27,1)$ & $321(84,7)$ \\
\hline Lebih & - & $4(1,0)$ & $9(2,3)$ & $13(3,4)$ \\
\hline \multicolumn{5}{|l|}{ Pendidikan } \\
\hline SD & $31(8,1)$ & $19(5,0)$ & $13(3,4)$ & $63(16,6)$ \\
\hline SMP & $40(10,5)$ & $37(9,7)$ & $30(7,9)$ & $107(28,2)$ \\
\hline SMA & $48(12,6)$ & $59(15,5)$ & $72(18,9)$ & $179(47,2)$ \\
\hline $\mathrm{D} 1 / \mathrm{D} 3$ & $3(0,8)$ & $6(1,6)$ & $5(1,3)$ & $14(3,7)$ \\
\hline $\mathrm{S} 1 / \mathrm{S} 2$ & $6(1,6)$ & $6(1,6)$ & $4(1,0)$ & $16(4,2)$ \\
\hline \multicolumn{5}{|l|}{ Penghasilan keluarga (juta) } \\
\hline$<1$ & $41(10,8)$ & $26(6,8)$ & $19(5,0)$ & $86(22,7)$ \\
\hline $1-2$ & $54(14,2)$ & $49(12,9)$ & $54(14,2)$ & $157(41,4)$ \\
\hline $2-3$ & $32(8,4)$ & $47(12,4)$ & $45(11,8)$ & $124(32,7)$ \\
\hline $3-4$ & $1(10)$ & $4(40)$ & $5(50)$ & $10(2,6)$ \\
\hline$>4$ & - & $1(0,2)$ & $1(0,2)$ & $2(0,5)$ \\
\hline \multicolumn{5}{|l|}{ Jumlah anak } \\
\hline 1 & $40(10,5)$ & $52(13,7)$ & $34(8,9)$ & $126(33,2)$ \\
\hline 2 & $34(8,9)$ & $29(7,6)$ & $30(7,9)$ & $93(24,5)$ \\
\hline 3 & $35(9,2)$ & $21(5,5)$ & $32(8,4)$ & $88(23,2)$ \\
\hline 4 & $11(2,9)$ & $14(3,6)$ & $23(6,0)$ & $48(12,7)$ \\
\hline$>4$ & $8(2,1)$ & $11(2,9)$ & $5(1,3)$ & $24(6,3)$ \\
\hline
\end{tabular}


Hasil pengukuran suhu tubuh selama tiga hari didapatkan sebagian besar anak demam, yaitu 246 $(64,9 \%)$ orang. Anak yang demam terbanyak pada kelompok susu formula, 98 (25,8\%) orang, kemudian diikuti kelompok ASI parsial 75 (19,7\%), dan ASI eksklusif 73 (19,2\%).

Nilai rerata suhu tubuh anak saat demam adalah $38,13 \pm 0,22^{\circ} \mathrm{C}$ dengan nilai rerata tertinggi pada kelompok yang mendapat susu formula. Dari semua anak yang demam, keseluruhan terjadi pada hari pertama $(98,3 \%)$. Waktu kejadian demam paling banyak terjadi pada enam jam pertama, yaitu antara pukul 12.00-18.00 WIB, diikuti enam jam kedua, antara pukul $18.00-00.00 \mathrm{WIB}$, dan paling sedikit terjadi pada 6 jam ketiga, antara pukul 00.00-06.00 WIB (Tabel 2).

Hubungan antara kejadian setelah pemberian imunisasi DPT 1 dengan pola ASI dilakukan dengan uji chi square. Hasil uji chi square didapatkan nilai $\mathrm{p}=0,001$, artinya terdapat perbedaan yang bermakna antara demam setelah imunisasi DPT 1 dengan pola ASI. Nilai risiko relatif (RR) untuk terjadi demam pada kelompok susu formula adalah 1,38 (IK 95\%:1,161,65) dibandingkan kelompok ASI eksklusif dan 1,33 (IK95\%:1,12-1,58) dibandingkan kelompok ASI parsial. Hal tersebut berarti susu formula merupakan faktor risiko untuk terjadinya demam pada bayi setelah imunisasi DPT 1 (Tabel 3).

Hubungan antara rerata suhu saat demam dengan pola ASI dilakukan dengan uji Kruskal-Wallis. Hasil uji Kruskal-Wallis ditemukan perbedaan yang bermakna antara nilai rerata suhu saat demam antara kelompok ASI eksklusif, ASI parsial, dan susu formula $(\mathrm{p}=0,001)$ (Tabel 4).

Analisis post hoc dengan uji Mann-Whitney dilakukan untuk mengetahui kelompok yang memiliki perbedaan antara kelompok ASI eksklusif dengan parsial, ASI eksklusif dengan susu formula, dan ASI

Tabel 2. Demam pada anak setelah imunisasi DTwP-1

\begin{tabular}{lcccc}
\hline Karakteristik demam & $\begin{array}{c}\text { Eksklusif } \\
\mathrm{n}(\%)\end{array}$ & $\begin{array}{c}\text { Parsial } \\
\mathrm{n}(\%)\end{array}$ & $\begin{array}{c}\text { Formula } \\
\mathrm{n}(\%)\end{array}$ & $\begin{array}{c}\text { Total } \\
\mathrm{n}(\%)\end{array}$ \\
\hline $\begin{array}{l}\text { Demam } \\
\text { Ya }\end{array}$ & $73(19,2)$ & $75(19,7)$ & $98(25,8)$ & $246(64,9)$ \\
$\quad \begin{array}{l}\text { Tidak } \\
\text { Jenis kelamin }\end{array}$ & $55(14,5)$ & $52(13,7)$ & $26(6,8)$ & $133(35,1)$ \\
$\quad$ Laki-laki & $38(15,4)$ & $36(14,6)$ & $45(11,8)$ & $119(48,4)$ \\
$\quad \begin{array}{l}\text { Perempuan } \\
\text { Lama demam }\end{array}$ & $35(14,2)$ & $39(15,8)$ & $53(13,9)$ & $127(51,6)$ \\
$\begin{array}{l}\text { Rerata } \pm \text { SD) } \\
\text { Waktu demam* }\end{array}$ & $38,0 \pm 0,22$ & $38,1 \pm 0,24$ & $38,2 \pm 0,16$ & $38,1 \pm 0,22$ \\
$12.00-18.00$ & $33(13,4)$ & $32(13,0)$ & $47(19,1)$ & $112(45,5)$ \\
$18.00-00.00$ & $28(11,3)$ & $29(11,7)$ & $26(10,5)$ & $83(33,7)$ \\
00.00-06.00 & $12(4,8)$ & $14(5,6)$ & $21(8,5)$ & $47(19,1)$ \\
Hari kedua & - & - & $4(1,6)$ & $4(1,6)$ \\
*Keterangan: Imunisasi diberikan saat jam kerja atau sebelum jam 12.00 &
\end{tabular}

* Keterangan: Imunisasi diberikan saat jam kerja atau sebelum jam 12.00

Tabel 3. Hubungan antara demam dengan pola pemberian ASI

\begin{tabular}{lccccc}
\hline \multirow{2}{*}{ Pola pemberian ASI } & \multicolumn{2}{c}{ Demam } & \multirow{2}{*}{ Total } & \multirow{2}{*}{ RR } & \multirow{2}{*}{ p $^{*}$} \\
\cline { 2 - 3 } \cline { 2 - 3 } Eksklusif & Ya & Tidak & & & \\
Parsial & 73 & 55 & 128 & 1,00 & 0,001 \\
Formula & 75 & 52 & 127 & 1,33 & \\
\hline Total & 98 & 26 & 124 & 1,38 & \\
\hline
\end{tabular}

*uji chi square 
Tabel 4. Hubungan antara rerata suhu saat demam dengan pola ASI

\begin{tabular}{lccc}
\hline Pola ASI & $\mathrm{N}$ & $\begin{array}{c}\text { Median } \\
(\text { min-maks })\end{array}$ & $\mathrm{p}^{*}$ \\
\hline Eksklusif & 73 & $38,10(37,6-38,4)$ & 0,001 \\
Parsial & 75 & $38,20(37,6-38,6)$ & \\
Susu Formula & 98 & $38,20(37,8-38,6)$ & \\
\hline
\end{tabular}

*uji Kruskal Wallis

Tabel 5. Hubungan antara demam dengan jenis kelamin, usia, dan status gizi

\begin{tabular}{|c|c|c|c|c|}
\hline & \multicolumn{2}{|c|}{ Demam } & \multirow{2}{*}{ Total } & \multirow{2}{*}{$\mathrm{P}^{*}$} \\
\hline & Ya & Tidak & & \\
\hline \multicolumn{5}{|l|}{ Jenis kelamin } \\
\hline Laki-laki & 119 & 64 & 183 & 0,962 \\
\hline Perempuan & 127 & 69 & 196 & \\
\hline \multicolumn{5}{|l|}{ Usia (bulan) } \\
\hline 2 & 117 & 60 & 177 & \\
\hline 3 & 100 & 62 & 162 & 0,398 \\
\hline 4 & 29 & 11 & 40 & \\
\hline \multicolumn{5}{|l|}{ Status gizi } \\
\hline Kurang & 36 & 9 & 45 & \\
\hline Baik & 200 & 121 & 321 & 0,043 \\
\hline Lebih & 10 & 3 & 13 & \\
\hline Total & 246 & 133 & 379 & \\
\hline
\end{tabular}

*uji chi square

parsial dengan susu formula. Didapatkan hasil nilai $\mathrm{p}=0,141$ kelompok ASI eksklusif dan ASI parsial, nilai $\mathrm{p}=0,001$ kelompok ASI eksklusif dan susu formula, dan nilai $\mathrm{p}=0,001$ kelompok ASI parsial dan susu formula.

Kelompok yang memiliki perbedaan nilai rerata suhu saat demam adalah antara kelompok ASI eksklusif dan susu formula serta kelompok ASI parsial dan susu formula. Sebaliknya, antara kelompok ASI eksklusif dan ASI parsial tidak terdapat perbedaan nilai rerata suhu saat demam.

Beberapa faktor lain yang mungkin memengaruhi demam setelah imunisasi DPT 1 adalah jenis kelamin, usia, dan status gizi (Tabel 5). Hubungan variabelvariabel tersebut dengan kejadian demam dilakukan dengan uji chi square. Kejadian demam setelah pemberian imunisasi DPT 1 tidak dipengaruhi oleh usia dan jenis kelamin. Sementara untuk status gizi ditemukan berhubungan dengan kejadian demam setelah imunisasi DPT $1(\mathrm{p}=0,043)$ dengan nilai $R R$ untuk terjadinya demam pada bayi dengan gizi kurang 1,28 (IK95\%: 1,08-1,52) dibandingkan dengan gizi baik. Gizi kurang merupakan faktor risiko untuk terjadinya demam setelah imunisasi DPT 1.

\section{Pembahasan}

Kami mendidapatkan frekuensi demam setelah imunisasi DPT 1 64,7\%. Hasil tersebut lebih besar jika dibandingkan dengan penelitian sebelumnya yang dilakukan oleh Pisacane $\mathrm{dkk}^{5}$ (38,2\%). Perbedaan ini disebabkan oleh vaksin yang digunakan. Kami menggunakan vaksin DTwP, sedangkan Pisacane menggunakan vaksin DTaP. Vaksin DTwP yang lebih sering mengakibatkan demam karena mengandung 3000 protein yang berbeda, sedangkan DTaP hanya mengandung dua sampai lima protein saja. ${ }^{6}$ Kohl $\mathrm{dkk}^{2}$ membandingkan kejadian demam pada anak yang mendapat vaksin DTwP dan vaksin DtaP. Kohl menemukan bahwa anak yang mendapat vaksin DTwP lebih banyak mengalami demam dibandingkan dengan yang mendapat DTaP (42,9\% berbanding 2,2\%).

Frekuensi anak yang mengalami demam dari kelompok susu formula 79\%, lebih banyak dibandingkan dengan kelompok yang mendapat ASI eksklusif dan ASI parsial. Hal tersebut juga serupa dengan penelitian yang dilakukan oleh Pisacane $\mathrm{dkk}^{5}(53 \%) .^{5}$ Setelah anak mendapat imunisasi DPT, monosit, makrofag, dan sel Kupfer akan mengeluarkan suatu zat kimia yang dikenal dengan pirogen endogen (IL-1, TNF, IL- 6, dan interferon) yang bekerja pada pusat termoregulasi hipothalamus untuk meningkat kan patokan termostat. Organ ini memicu peningkatan suhu tubuh. Berbagai komponen yang terkandung di dalam ASI, berupa komponen anti mikroba dan anti inflamasi mencegah infeksi dan memodulasi sistem imun sehingga akan mengurangi produksi sitokin proinflamasi dan mengurangi demam. ${ }^{4}$ 
Nilai suhu rerata tubuh saat demam pada kelompok susu formula didapatkan lebih tinggi dibandingkan dengan kelompok ASI eksklusif dan ASI parsial. Hal tersebut juga serupa dengan hasil penelitian Pisacane dkk. ${ }^{5}$ Produksi sitokin proinflamasi dikurangi tidak hanya oleh komponen ASI saja, tetapi juga oleh proses menyusui itu sendiri yang dapat memberikan pemenuhan kebutuhan emosional bayi. Anak yang sakit akan sering menyusu untuk mengurangi rasa tidak nyaman dan mendapatkan dukungan emosional dari kontak langsung dengan ibu mereka. Pada anak setelah imunisasi, asupan kalori yang berkurang banyak dilaporkan pada kelompok yang mendapat susu formula. Hal tersebut dikaitkan dengan peningkatan serum leptin, interleukin proinflamasi, dan TNF serta memiliki risiko yang lebih tinggi untuk terjadi demam. ${ }^{5,7}$ Nilai risiko relatif anak yang mendapat ASI parsial 1,33 dan susu formula 1,38. Artinya, pola pemberian ASI merupakan faktor risiko untuk kejadian demam setelah imunisasi DPT 1. Dengan kata lain, bayi yang mendapat ASI parsial akan mengalami demam 1,33 kali dan anak yang mendapat susu formula 1,38 kali dibandingkan dengan anak yang mendapat ASI eksklusif.

Terdapat perbedaan suhu rerata tubuh saat demam pada masing-masing kelompok. Kelompok yang memiliki perbedaan suhu tubuh saat demam adalah antara kelompok ASI eksklusif dan susu formula serta kelompok ASI parsial dan susu formula, sedangkan antara kelompok ASI eksklusif dan ASI parsial tidak terdapat perbedaan suhu tubuh saat demam.

Berdasarkan waktu terjadinya demam, hampir semua anak yang demam terjadi pada hari pertama setelah pemberian imunisasi DPT (98,3\%). Hanya empat anak yang mengalami demam pada hari kedua. Demam terbanyak terjadi pada sore hari antara pukul 12.00 sampai dengan 18.00 WIB. Hal tersebut juga serupa degan penelitian Pisacane dkk, ${ }^{5}$ demam 90\% terjadi pada hari pertama. Sesuai dengan teori, bahwa demam yang disebabkan imunisasi biasanya berdurasi pendek dan terjadi selama 24 jam setelah imunisasi. ${ }^{4-6}$

Kami tidak mendapatkan anak yang mengalami hiperpireksia (suhu tubuh $\geq 39,0^{\circ} \mathrm{C}$ ). Suhu tubuh tertinggi didapatkan $38,5^{\circ} \mathrm{C}$ yang terjadi pada hari pertama di 6 jam pertama (antara pukul 12.00-18.00 WIB). Berbeda dengan penelitian Pisacane dkk yang menemukan $8(1,7 \%)$ anak mengalami hiperpireksia. Hal tersebut bisa disebabkan oleh tingkat perhatian ibu yang tinggi terhadap kemungkinan demam pada anaknya. Begitu tubuh anaknya dirasakan hangat, dianjurkan untuk mengukur suhu tubuh anak per jam. Jika suhu mencapai $\geq 37,5^{\circ} \mathrm{C}$ maka ibu dapat memberikan parasetamol. ${ }^{5}$

Hasil analisis hubungan antara usia dan jenis kelamin dengan kejadian demam setelah imunisasi DPT 1 menunjukkan tidak terdapat hubungan antara kedua variabel. Sebaliknya, terdapat hubungan antara status gizi dengan demam setelah pemberian imunisasi DPT 1. Hal tersebut kemungkinan disebabkan karena gizi kurang yang akan menghambat respon imunitas dan meningkatkan risiko terjadi infeksi. Kekurangan gizi pada anak berkaitan dengan gangguan imunitas berperantara sel (cell-mediated immunity), fungsi fagosit, sistem komplemen, dan produksi sitokin. ${ }^{4}$

Penelitian ini memiliki beberapa keterbatasan, di antaranya pemberian imunisasi dilakukan oleh tenaga medis yang berbeda, yaitu petugas imunisasi masingmasing Puskesmas. Pengukuran suhu tubuh dilakukan oleh ibu bukan oleh tenaga kesehatan profesional. Walaupun para ibu telah dilatih untuk mengukur suhu tubuh secara aksila menggunakan termometer digital dan mencatat nilai tersebut di kartu harian, ini tetap dapat menjadi bias penelitian. Demam yang terjadi setelah imunisasi DPT dapat merupakan sebuah episode infektif. Walaupun demam yang biasanya berdurasi pendek dan terjadi selama 24 jam setelah imunisasi biasanya bukan sebagai infeksi.

\section{Kesimpulan}

Pemberian ASI dapat mencegah kejadian demam setelah imunisasi DTwP-1. Namun, masih diperlukan penelitian lebih lanjut yang harus menggunakan metode penelitian yang lebih objektif, seperti pemberian imunisasi oleh tenaga kesehatan yang sama dan pengukuran suhu tubuh bayi juga oleh tenaga kesehatan yang sama.

\section{Daftar pustaka}

1. Depkes RI. Pedoman Penyelenggaraan Imunisasi. Departemen Kesehatan RI Jakarta: Depkes;2004.

2. Kohl KS, Marcy SM, Blum M. Fever after imunization: current concepts and improved future scientific understanding. Clin Infect Dis 2004:39:389-94.

3. Ranuh IGN, Suyitno H, Hadinegoro SH, Kartasamita 
CB, Ismoedijanto, Soedjatmiko. Pedoman Imunisasi di Indonesia. Edisi ketiga. Jakarta: Badan Penerbit IDAI; 2008.

4. Dinarello CA. Infection, fever, and exogenous and endogenous pyrogens: some concepts have changed. J Endotoxin Res 2004;10:201-22.

5. Pisacane A, Continisio P, Palma O, Cataldo S, De
Michele F, Vairo U. Breastfeeding and risk for fever after Imunization. Pediatrics 2010;125:1448-52.

6. Moylett EH, Hanson C. Mechanistic actions of the risk and adverse events associated with vaccine administration. J Allergy Clin Immunol 2004;114:1010-20.

7. Eglash A. Montgomey A, Wood J. Breastfeeding. Dis Mon 2008;54:343-411 